Meta

Journal des traducteurs

Translators' Journal

\title{
A Problem of Russian-to-English Translation: Aspectual Opposition in Infinitival Constructions
}

\section{Stephen Capaldo}

Volume 31, numéro 2, juin 1986

URI : https://id.erudit.org/iderudit/002201ar

DOI : https://doi.org/10.7202/002201ar

Aller au sommaire du numéro

Éditeur(s)

Les Presses de l'Université de Montréal

ISSN

0026-0452 (imprimé)

1492-1421 (numérique)

Découvrir la revue

Citer cet article

Capaldo, S. (1986). A Problem of Russian-to-English Translation: Aspectual

Opposition in Infinitival Constructions. Meta, 31(2), 145-152.

https://doi.org/10.7202/002201ar 


\title{
A PROBLEM OF RUSSIAN-TO-ENGLISH TRANSLATION : ASPECTUAL OPPOSITION IN INFINITIVAL CONSTRUCTIONS
}

\author{
STEPHEN CaPAlDo \\ TRANSLATOR, FREDERICTON
}

Most people would probably agree that one of the most difficult elements of learning Russian is that of mastering its verbal aspects. While the salient points thereof are outlined in great detail in the works of Rassudova, Xavronina, Źidkova, Bondarko and Forsyth, for the purposes of this article I shall only briefly recapitulate what is involved in the use of Russian verbal aspects.

The imperfective aspect has three major uses :

a) it denotes an action in process ;

b) it denotes a repeated action;

c) it provides a general definition of the action.

The unifying characteristic among these three uses is general emphasis on the action itself rather than on its result.

The perfective aspect has two major uses :

a) it denotes one concrete fact ( = a punctual event) at one precise moment, not at present ;

b) it stresses the result of a completed action.

(There are two other minor categories which could be passed over for the time being.)

The unifying characteristic between the two applications of the perfective aspect is the desire of the speaker to see the action as one temporally limited, indivisible whole. Thus the unifying characteristic of the perfective is much more limited than that of the imperfective with its emphasis on general action.

The main feature of Russian aspectual usage which is at once curious and disconcerting for the foreign-language student is aspectual contrast. (Aspectual contrast is roughly defined as the possibility of using either aspect in the same context in grammatically correct fashion with the evident change of meaning inherent in aspectual usage.) I shall attempt to analyse three different cases where an infinitive in either aspect can be used in Russian and offer possible translations into English for each of these cases. Then, I shall make some concluding remarks about aspectual contrast and offer some models for translation of passages constituting examples of such contrast.

\section{MODEL WORDS PLUS INFINITIVE}

The first case I shall examine is the construction of a so-called "modal word", plus infinitive (have to, it is necessary, must, may, it is time to). When the imperfective infinitive follows a modal word very often we are dealing with the so-called "Procedure to the Action". In other words, when all preparations for an action have been completed, the action may or must begin.

Ex. Has everyone finished eating? (perfective)

Fine. Now tea may be served. (imperfective) 
When the perfective infinitive follows a modal word, a "general necessity" for a result is usually indicated ; otherwise, apparent negative consequences will accrue.

Ex. Did you call to inform him of the meeting?

No? Well, you have to call. It is absolutely essential.

(Perfective, warning of possible unpleasant consequences)

Now I shall discuss more specific examples from Russian.

(1) a) Nado (pora) sobirat'sja (impt. inf.) domoj

b) Nado (pora) sobrat'sja (perf. inf.) domoj

The general idea is that of having to proceed homeward. In a), however, it is the imperfective infinitive which is used. Let us imagine the following scenario :

We are at the beach. We have passed a pleasant afternoon resting and recreating. It is getting to be time to head back but there is as yet no great need to rush or any circumstances indicating that there will be unpleasant consquences unless immediate concrete action is taken. Then (1. a) would ostensibly follow.

Possible translations :

(1.) a) It's time to get going.

We's better be heading back.

It's time to get our things together and be going

We'd better get organized and be heading out.

There are obviously other possible variants, but in all four I have tried to find words or expressions to indicate the start or proceeding to the action, result unstressed and hence unimportant at the moment of speech.

For (1.b) we shall assume that we are the beach. However, while sitting we see storm clouds on the horizon moving toward shore very quickly. Then b) would be used, as the implications of not moving quickly and obtaining a result in order to eliminate possible unpleasant consequences are clear and apparent to all speakers of Russian. Use of a) in such a setting would be, if not incorrect according to our definition of contrast, at the very least unusual and tend to indicate the individual's lack of comprehension of the situation or failure to take it seriously or in a way relevant to him personally.

Possible translations :

b) We've got to get out of here.

It's time to head out now!

We've got to head back.

It's time to get our things together and go!

In my translations I have tried to indicate the relative urgency of the situation by avoiding process words such as " -ing" participles.

(2) a) Nužno (nado) zakančivat' (impf. inf.)

b) Nužno (nado) zakončit' (pf. inf.)

The general idea is that of the need to finish something. For both 2. a) and b) our scenario will be the classroom at the end of a lesson.

For a), let us suppose that the lesson is going smoothly and that the teacher then notices the time, which has run out or almost run out. There is no other reason for concern except that time appears exhausted. (2. a) would then be used. If, on the other hand, students are milling about outside and a bell has rung, two possible circumstances which will tend to concretize the action for the Russian speaker and lend more urgency 
to it, then (2. b) would probably be used to indicate the need to achieve a result for the requisite action.

Possible translations :

(2) a) It's time to finish up.

We have to finish up.

Time to wind it up.

Here I have tried to use expressions or idioms indicating that the termination of the preceding action is not what is critical, merely that the termination should begin. This underscores the crucial difference between the aspects : the imperfective emphasizes the activity of termination itself (even though there is/was/will be a result), whereas the perfective emphasizes the concrete result of the same activity. Thus for ( 2 . b) I offer :

We've got to finish.

Time to end today's lesson. (Even possibly in context) :

Time to go. (Presuming that the "finish" of the lesson has already been achieved.),

And one more example with modal words :

(3) a) Možno pristupat' $k$ čteniju ètoj knigi (impf. inf.) Možno pristupit' $k$ čteniju ètoj knigi (pf. inf.)

The general idea is that the reading of a book may begin. Our scenario will be that of a book assigned for reading outside of class. For (3. a) one possible situation would be that we have been assigned a series of books or materials which have already been completed (perfective) to the instructor's satisfaction, such that now the class is ready to proceed to the reading of this next book, to the next stage of preparation in the course. The result is once again unimportant, merely the fact that now this part of the course is free to begin.

For (3. b) we may presuppose either a previously unbeeded admonition about starting the reading of the book, in which case the instructor now rather pointedly urges that the start of the enterprise be completed or a situation where a student factually enquires whether such and such a book may be begun and receives the appropriate concrete response in the perfective aspect.

Possible translations for (3. a) :

You may now proceed to this book.

You may now get started on this book.

You may now undertake reading of this book.

For (3. b) :

You may now begin this book.

(Or by tone possibly) : Please begin reading this book.

You may now start this book.

Please start this book.

In (3. a) we try to emphasize in our translations the beginning of an action, in (3. b) the completion of the beginning. 


\section{VERBS DENOTING MENTAL ACTIVITY PLUS INFINITIVE}

Generally speaking, the expressions involved here indicate actions such as decide, occur to, be resolved, etc. The imperfective infinitive thereafter indicates that a particular action is to be merely performed, the perfective that it is to be not only performed but completed as well, with the emphasis squarely on its final result.

(4) a) My prinjali rešenis uezžat' (impl. inf.)

b) My prinjali rešenie uexat' (pf. inf.)

The general idea is that a decision has been made to leave (a country, for example).

In (4. a) let us say that a decision has been made to emigrate from Canada in order to assume residence in another country. Not necessarily that we have been driven to it for fear of penalty, but at the moment of speech we wish to indicate that circumstances had evolved to the point where the act of leaving would be better. We would use (4. a) to state that a decision had been made to pursue or attempt (not necessarily complete successfully) a particular course of action, that of leaving. There is no reference to or concern with the result of the action. In (4. b) we state our decision to achieve the result of leaving. We see ourselves not in the process of gathering documents and possessions but rather out of the country at some point after the moment of speech. We use (4. b) perhaps again out of a feeling of urgency that we need to be gone. We may and undoubtedly do envisage such a result in a) as well. However, at the crucial moment of speech we are not stressing that particular aspect of the action in (4. a).

Possible translations :

(4) a) We have decided to emigrate

We have decided to begin the emigration process.

We have decided to pursue the course of emigration.

b) We have decided to emigrate from here.

We have decided to leave the country.

(Or if clear from the context) : We have decided to get out.

Another example :

(5) a) $M y$ rešili otgovarivat' ego (impf. inf.)

b) My rešili otgovorit' ego (pf. inf.)

The idea is of a decision to dissuade someone, let us presume for the sake of argument, a son from marriage. In (5. a) once again we note our decision to pursue or attempt a particular course of action, with the result's being unimportant at the moment of speech. We have listened to our son's reasons for wanting to get married, perhaps tried to suggest possible alternatives for the nonce, but nothing works. Now we are resolved to embark upon a dissuasion process (5. a). We hope to attain a result, but the action - as distinct from other courses of action - is what matters here. In (5. b), we show our decision to achieve the desired result. We see our efforts as being urgent and eventually successful, hence the perfective. We limit the action and render it poignant at $/$ to the moment of speech. We view it as an indivisible whole. 
Possible translations :

(5) a) We have decided to try to dissuade him.

We have decided to embark upon a dissuasion process.

We have decided upon dissuasion.

(5) b) We have decided to dissuade him.

We have decided to get him to change his mind.

We have decided to work on him with a view toward his reconsidering.

In (5. b) the variants get long, and in concrete translation situations perhaps a bit unwieldy and impractical, but for the moment it is the principle of aspectual differentiation which is being analyzed.

One more example from this group :

(6) a) Voznikla u menja mysl' uxodit' (impf. inf.)

b) Voznikla u menja mysl' ujti. (pf. inf.)

The idea is that is has occurred to me to leave a place (room, office, etc.). Let us presume that we are leaving a party. In (6. a) the party may or may not be going well but in any event at a particular point in time we got the idea of performing one particular action over another, of leaving as opposed to staying, talking, eating, drinking. It may be moderately late, but once again, no pressing imperative dictating the need for an immediate exit. In b) however, there would probably be such an imperative. The lateness of the hour, an insult suffered, the last straw of an evening of insipid chatter with the other guests, etc. The feeling is that all of a sudden we realized that there was no need to tolerate this, so we should be gone (not that we should begin the act of leaving or perform that as compared with another action) but that we should see ourselves on the outside of the venue of the action, gone departed.

Possible translations :

(6) a) The thought occurred to me to get going.

The thought occurred to me to be on my way.

The thought occurred to me to get started home.

b) The thought occurred to me to get gone.

The thought occurred to me to depart.

The thought occurred to me to leave.

VERBS OF MOTION PLUS INFINITIVE ${ }^{1}$

The infinitive in the two aspects after a verb of this group can express the same nuances as already described in 2. 1. and 2. Hence, we shall enter straightway into the examples and analysis thereof.

(7) a) mezonëv (Maisonneuve) priexal v Ameriku zavoevynat' zemli dlya Lui (Louis) XIII i obraščcat'v ristianstvo indejcev. (impf. inf.) (N.B. Underlined verbs are in fact in the imperfective in the original.)

b) Mezone'v (Maisonneuve) priexal v Ameriku zavoevat' zemli dja Lui (Louis) III $i$ obratit' $v$ xristianstvo indejcsev. (pf. inf.)

The idea is that Maisonneuve came to North America to win lands for the King of France and to convert the Indians to Christianity. In (7. a) the verbs win and convert indicate general orders issued to Maisonneuve. It was to be his task to do these things on 
an habitual bases. In order for (7. b) to be acceptable it would have been necessary for the King to have given Maisonneuve orders - perhaps on the basis of rumours, reports or previous visits to North America - to capture a specific group of lands viewed as a whole and to convert a specific group of Indians, also viewed as a whole.

Possible translations :

(7) a) Maisonneuve came to America to win lands for Louis XIII and to convert Indians to Christianity.

Maisonneuve came to America to engage in the winning of lands for Louis XIII and the converting of Indians to Christianity.

Maisonneuve came to America in order to win lands for Louis XIII and to convert Indians to Christianity.

(7) b) Maisonneuve came to American to win the (aforementioned) lands for Louix XIII and to convert the (aforementioned) Indians to Christianity. Maisonneuve came to America to win these (aforementioned) lands for Louix XIII and to convert the (aforementioned) Indians to Christianity. Maisonneuve came to American with the mission of winning those lands for Louis XIII and converting those Indians to Christianity.

Without some type of specifier or qualifier sentences b) become logically rather difficult to sustain unless we are functioning on the basis of previously obtained information and previous conversations allowing us to be certain of the concretization and resultivization of the action.

(8) a) Šomedi (Chomedey) otpravilsja $v$ novyj svet ispolnjat' objazannosti revnostvoto katolika, kak on ponimal ix (impf. inf.) (N.B. Underlined verbs are in fact in the imperfective in the original.)

b) Šhomedi (Chomedey) otpravilsja v novyj svet ispolnit' objazannosti revnostnoto katolika, kak on nominal ix (pf. inf.)

The idea is that Chomedey came to perform the duties of a zealous Catholic, as he understood them. The same argumentation applied as for the first pair of this section; (8. a) would be used to indicate general orders given to a devout practising Catholic, whereas (8. b) would indicate specific obligations given with the expectation that they would be fulfilled with a tangible result (e.g. evidence of mass-conversion of Indians to Catholicism), which result is preponderant at the moment of speech. It would be possible to use (8. b) in this case as well only on the basis of positive information concretizing the action ${ }^{2}$.

Possible translations :

(8) a) Chomedey set out for the New World to fulfill the duties of a zealous Christian, as he understood them.

Chomedey set out for the New World in order to fulfill the duties of a zealous Christian, as he understood them.

Chomedey set out for the New World to engage in fulfilling the duties of a zealous Christian, as he understood them.

(8) b) Chomedey set out for the New World to fulfill the duties of a zealous Christian, as he understood them.

Chomedey set out for the New World in order to fulfill the duties of a zealous Christian, as he understood them.

Chomedey set out for the New World with the purpose (goal, aim) of fulfilling the duties of a zealous Christian, as he understood them. 
The reader will note that $I$ have some difficulty differentiating a) from $b$ ) translations here due to the nature of the English verb "fulfill".

(9) a) Kolumb (Columbus) priplyl $v$ novy svet otkryvat' novuju stranu (impf. inf.)

b) Kolumb (Columbus) priplyl v novy svet otkryt' novuju stranu. (pf. inf.) land.

The message here is that Columbus sailed to the New World to discover a new

(9. a) again tells us that Columbus was charged with performing a function, result unstressed. Moreover, discovering a land is often conceived in most languages, I daresay, as a process. To use (9. b) would again indicate that specific orders were expected to be fulfilled and tangible results offered, e.g. were the King to come visiting he would expect to see thriving colonies in the new land.

Possible translations :

(9) a) Columbus sailed to the New World (in order) to discover a new land. Columbus sailed to the New World to engage in the discovery of a new land.

Columbus sailed to the New World to pursue the discovery of a new land.

(9) b) Columbus sailed to the New World (in order) to discover a new land.

Columbus sailed to the New World to found a new land.

Columbus sailed to the New World to open up a new land.

(Or possibly) : Columbus sailed to the New World to settle a new land.

The dichotomy in aspectual use is, I think, clear in these translations.

On the basis of my exposé and examples, I offer the following summary comments for thought and constructive criticism.

Once some of the contexts of aspectual contrast have been grasped it is possible to proceed to the translation of same and the establishment of translation models. On the basis of the above work I would offer three possible models for translation of the infinitive after specific groups of verbs.

1. Semantic equivalency in translation of the infinitive construction. E.g. :

voznikla mysl' ujti (pf.) - the idea came to leave, depart

voznikla mysl' uxodit' (impf.) - the idea came to get going

For all intents and purposes the English variants are semantically equivalent in meaning and length to the Russian.

2. Embellishment upon semantic meaning of the infinitive construction. E.g. :

nado sobirat'sya domoj (impf.) - to get our things together and be going.

rešili otgovarivat' (impf.) - to embark upon a dissuasion process.

Priexal zavoëvyvat' zemli (impf.) - to engage in the winning lands.

Here the semantic content is equivalent but its expression is longer.

3. Idiomatization (with potential embellishment) semantically unrelated to the criginal. E.g. :

rešili otgovorit'(pf.) - to get him to change his mind, to work on him with a view toward his reconsidering.

prinyali rešenie uezžat' (impf.) - to begin the emigration process, to pursue the course of emigration.

nado zakancivat' (impf.) - time to wind it up.

The original semantic content of the Russian has been changed in English 4 . 
If we take all the examples given in this preliminary study and relate them to either 1, 2 or 3 above, it would appear that our b) perfective examples lend themselves more often and more easily to semantic equivalency translation ( 7 of 9 examples by my reasoning), which is quite logical in a way, as the perfective is reserved for communication of one temporally limited concrete fact, while our a) imperfective examples, while much of the time translatable by semantic equivalency, do indeed very often lend themselves to 2 or 3 ( 7 of 9 examples here too). This also makes some sense in that the imperfective very often dwells on the duration of an action while the perfective underscores its result.

Of 9 imperfective infinitives, in the author's opinion, translation best done

a) by semantic equivalency

b) with embellishment

c) by idiomatization
a) $2 / 9$
b) $6 / 9$
c) $1 / 9$

Of 9 perfective infinitives, in the author's opinion, translation best done
a) by semantic equivalency
b) with embellishment
c) by idiomatization
$\begin{array}{lll}\text { a) } 7 ? 9 & \text { b) } 1 / 9 & \text { c) } 1 / 9\end{array}$

Notes

1. The first two of the three examples in this section are taken from the Vail-Genis article on Canada which appeared in the mid-July 1981 issue of Novyj Amerikanets.

2. Forsyth devotes time to a discussion of positive vs. negative reasons for choosing one or the other aspect in A Grammar of Aspect. 